\title{
Fracture resistance of mollars with MOD cavities restored with different materials
}

\author{
RUXANDRA MĂRGĂRIT ${ }^{1}$, IOANA SUCIU ${ }^{2}$, DANA CRISTINA BODNAR ${ }^{1}$, MIHAELA GRIGORE ${ }^{2}$, \\ SÎNZIANA ADINA SCĂRLĂTESCU ${ }^{2}$, OANA CELLA ANDREI ${ }^{4}$, CĂTĂLINA MURARIU \\ MĂGUREANU ${ }^{4}$, MIHAELA CHIRILĂ ${ }^{2}$, ANGELICA BENCZE ${ }^{3}$, ECATERINA IONESCU ${ }^{3}$
}

\author{
${ }^{1}$ Department of Restorative Odontotherapy, Faculty of Dental Medicine, "Carol Davila" University of \\ Medicine and Pharmacy, Bucharest, Romania \\ ${ }^{2}$ Department of Endodontics, Faculty of Dental Medicine, "Carol Davila" University of Medicine and \\ Pharmacy, Bucharest, Romania \\ ${ }^{3}$ Departament of Ortodontic and Dento-Facial Ortophedy, Faculty of Dental Medicine, "Carol Davila" \\ University of Medicine and Pharmacy, Bucharest, Romania \\ ${ }^{4}$ Departament of Mobile Prostodontics Faculty of Dental Medicine, "Carol Davila" University of \\ Medicine and Pharmacy, Bucharest, Romania
}

\begin{abstract}
Restoring teeth with second class cavities is a challenge in dentistry. Both the carious process and the preparation of the cavity for the dental restoration reduces the tooth resistance to the masticatory forces. It has been shown that modern aesthetic materials using an adhesive system improve the stress resistance of the restored teeth. There is a series of studies that attempted to determine the type of optimal material that would provide increased resistance to occlusal demands. In the present study we tried to determine the fracture resistance of molars with second class cavities restored with different categories of aesthetic materials. Thus, forty intact molars were divided into five groups of 8 teeth, MOD cavities were prepared and the teeth were restored with three types of materials: nanofilled composite, mycrohibrid composite and ormocer. The teeth of the first group were left unprepared, and those belonging to the second group were subjected to the preparation of MOD cavities but were not filled. Samples were subjected to compression using an Universal Loading Machine (Lloyd Instruments) and the value of the force they failed was recorded. Intact teeth showed the highest resistance to compression and those with MOD cavities prepared but not filled showed the smallest. Of the groups that benefited from restoration with filling material, the teeth restored with ormocer had the highest resistance, followed by those restored with nanofilled composite, and finally by those restored with mycrohibrid composite.
\end{abstract}

Keywords Mesio-occlusal-distal (MOD) cavities, fracture resistance, dental restoration materials.

To cite this article: MĂRGĂRIT R, SUCIU I, BODNAR DC, GRIGORE M, SCĂRLĂTESCU SA, ANDREI OC, MĂGUREANU CM, CHIRILĂ M, BENCZE A, IONESCU E. Fracture resistance of mollars with MOD cavities restored with different materials. Rom Biotechnol Lett. 2021; 26(1): 2323-2330. DOI: 10.25083/rbl/26.1/2323.2330 


\section{Introduction}

Nowadays, from the desire to ensure physiognomy, the most commonly used filling materials are resin-based composites. Composite resins have long been used to restore posterior teeth. It has been shown that composite materials are preferred in the situation of MOD cavities restorations [1]. In the case of MOD cavities preparations, the dental resistance decreases both by reducing the dental tissue as much as by the loss of the enamel margins. Loss of the dental tissue predisposes to an increase risk of dental fractures. Restoring dental integrity and providing adequate resistance can be accomplished through a direct filling or an onlay. It has been shown that ceromers - second-generation laboratory composite - have both elasticity and fracture resistance comparable to direct composites [2, 3]. Indirect restoration using ceromers ensures a high resistance to occlusal demands, but the use of composite resins for direct restorations can provide similar resistance [4]. Due to the fact that onlay dental procedure leads to an extra loss of dental tissue [5], direct restoration through composite resins is the most common treatment method chosen. Restorations with composite resins provides favorable resistance to occlusal overload. The composite has the ability to absorb the forces transmitted to the dental level and to transmit lower forces to the dental tissues [6]. Additionally, the introduction of adhesive systems had a beneficial effect on the increase of dental resistance to occlusal overloads [7]. Some studies presented in the literature have shown that the use of adhesive systems can counterbalance the loss of dental resistance due to the reduction of dental tissue following cavity preparation [8, 9]. The use of dentinal adhesives reduces deformation of cusps under occlusal loading [10]. At the same time, the use of dentinal adhesives reduces the risk of fracture, stabilizing the tooth and reinforcing the dental structure $[11,12]$. The problem of composite resins restorations is related to the occurring possibility of marginally gaps due to polymerization shrinkage, which can lead to lack of strength, especially in the case of MOD restorations [13, 14]. Among the factors that influence the resistance of the dental units are the type of the cavity, the amount of lost dental tissue, the filling technique as well as the composition of the composite materials $[15,16]$. The second class cavities and especially those of MOD type are most predisposed to the occurrence of dental fractures, especially as the amount of lost dental tissue is significant. When preparing cavities for adherent materials, a smaller amount of dental tissue is removed as compared to preparation for non-adherent material, with dental resistance being less affected but still at risk of fracture. Regarding the filling technique, studies have been conducted on dental resistance in the case of bulk-fill or incremental layering techniques. HEGDE et al. [17] showed that restored teeth using high-viscosity bulk-fill nanocomposites showed fracture resistance comparable to those restored using ususal nanocomposite, while the resistance of those restored by bulk-fill giomer was lower. Contrary to Hedge's study, Ilie and FLEMING [18] have shown that high-viscosity bulk-fill giomers have higher resistance compared to conventional composite materials. In a study conducted by ROSATTO et al. [19] it was shown that restored teeth by bulk-fill technique show a higher fracture resistance than those restored by incremental layering technique. RAUBER et al. [20] showed that there are no differences regarding stress resistance in the situation of restorations by bulk-fill technique or incremental layering technique. There are studies in the literature that show that the choice of coronary filling material is an important stage of dental treatment, the resistance to the occlusal demands of the restored teeth depending on it [21]. Microhybrid composites containing particles with diameters ranging from $0.4 \mu \mathrm{m}$ to $1.0 \mu \mathrm{m}$ are frequently used for dental restorations of both anterior and posterior teeth. Another alternative for the coronary restoration of MOD cavities is composite resins, which contain nanoparticles, which exhibit certain characteristics such as lower polymerization shrinkage but also high mechanical properties. Nanoceramic composites can also be used for dental restoration. Shortly before the year 2000, a new type of ceramic modified composite resin was introduced as a tooth filling material - ormocer. The aim of this study was to compare the fracture resistance of intact teeth with MOD cavities prepared and restored by various dental materials (mycrohibrid composite, nanofilled composite and ormocer).

\section{Material and Method}

Forty intact without cavities or filling extracted third molars were used. They were divided into five groups (G1, G2, G3, G4 and G5) of 8 teeth. After removing the soft tissue, the teeth were cleaned, put in the chloramine solution for 48 hours and stored in the physiological serum until the cavities were prepared. The teeth belonging to the first group were not prepared, representing the control group. For the teeth belonging to the G2 group it have been prepared MOD cavities but have not been restored. Regarding the other three groups, MOD cavities were prepared and were restored with different adhesive materials. Thus, for the G3 group an ormocer was used, nanofilled composite was used for G4, and mycrohibride composite was used for G5. The access was created with 
a spherical burr at high speed, the rest of the cavity being prepared with a cylindrical burr also at high speed. Each cavity was prepared (Fig. 1) with an individual burr, all the cutter instruments being identically. The preparation was

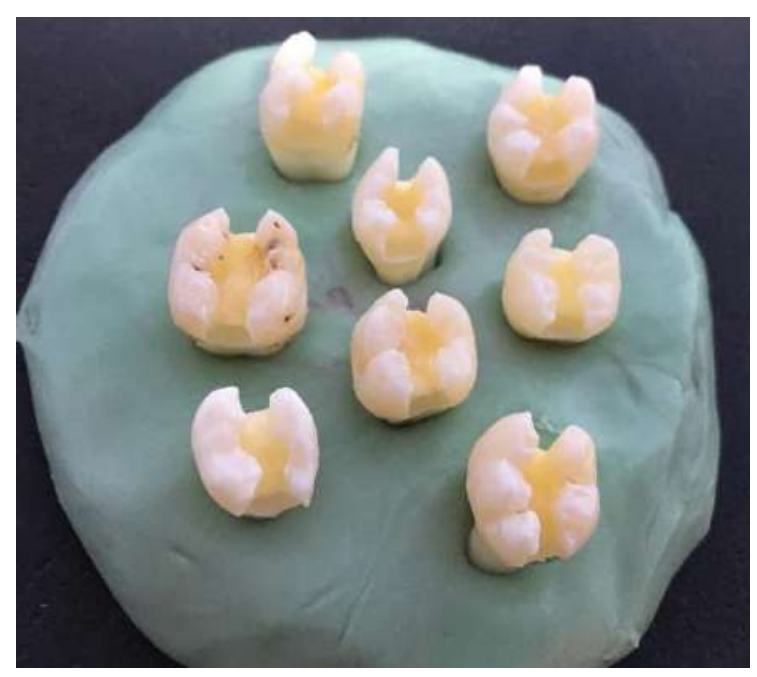

Figure 1. MOD preparation

To achieve the experiment, cylindrical conformers were used, the teeth being inserted into a class III gypsum (Fig. 3). The material surrounded the dental units on the entire surface. The enamel-cement junction was identified, so the teeth were inserted only with the root portion into the support material. The gingival walls of the vertical done with cooling. After preparation, the cavities were washed and dried, followed by etching, application of adhesive system and coronary filling material (Fig. 2) by incremental layering technique.

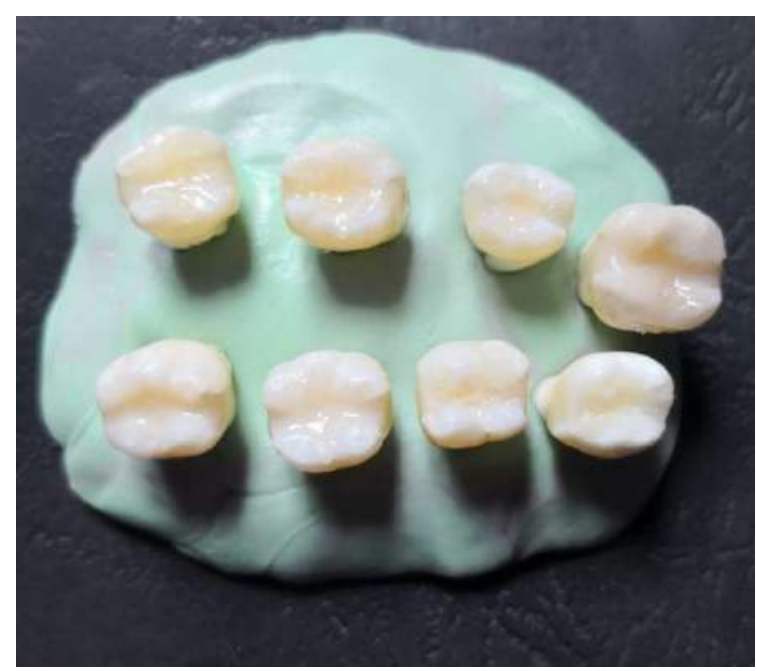

Figure 2. MOD restoration

cavities were supragingivally. To assess fracture resistance, the samples were placed in an Universal Loading Machine (Lloyd Instruments) (Fig. 4) and subjected to vertical compression at a speed of $1 \mathrm{~mm} / \mathrm{min}$, recording data on the strength to which the samples failed.

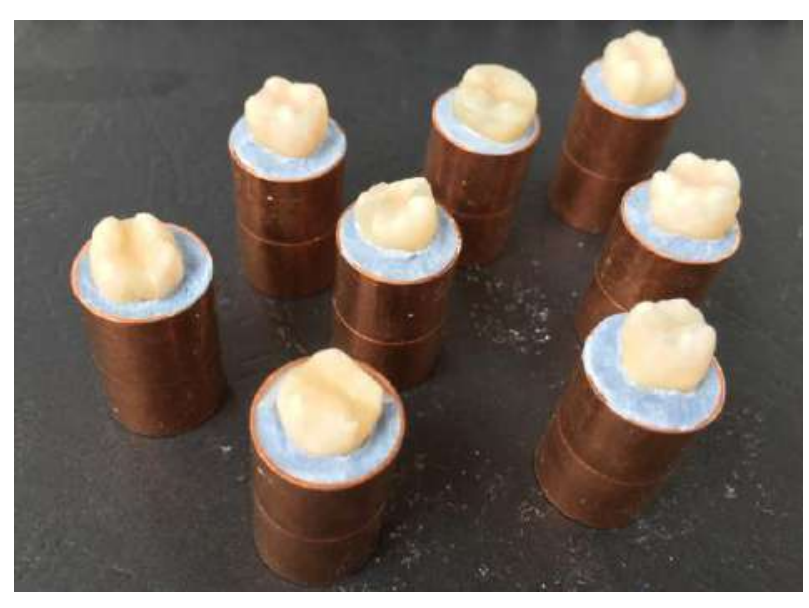

Figure 3. Cylindrical conformers

\section{Results}

Group G1 - unprepared and unrestored teeth: the smallest load that determines the sample failure was

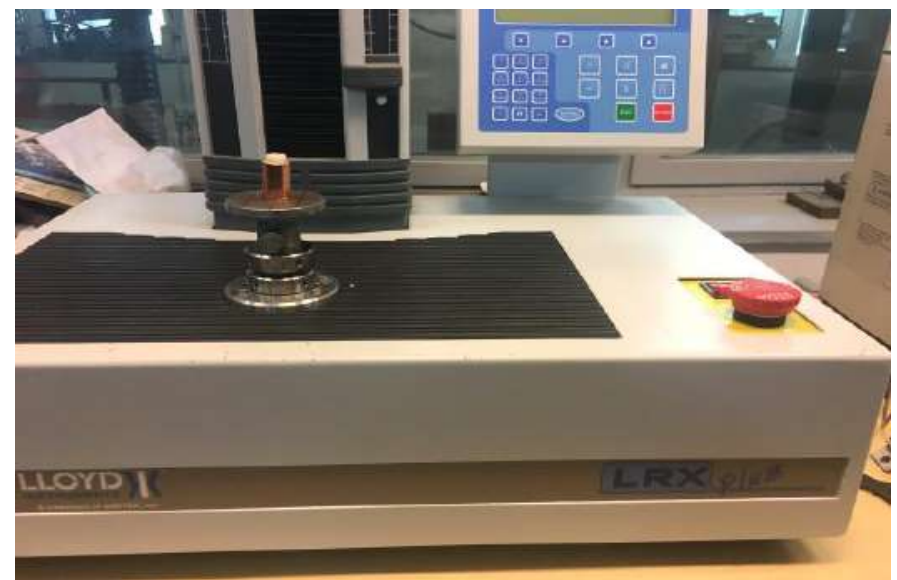

Figure 4. Samples placed in an Universal Loading Machine

$3050 \mathrm{~N}$ and the highest strength was $3070 \mathrm{~N}$, the mean value being $3061.75 \mathrm{~N} \pm 7.44 \mathrm{~N}$ (standard deviation). The diagram representing the maximum value is illustrated in Fig. 5. 


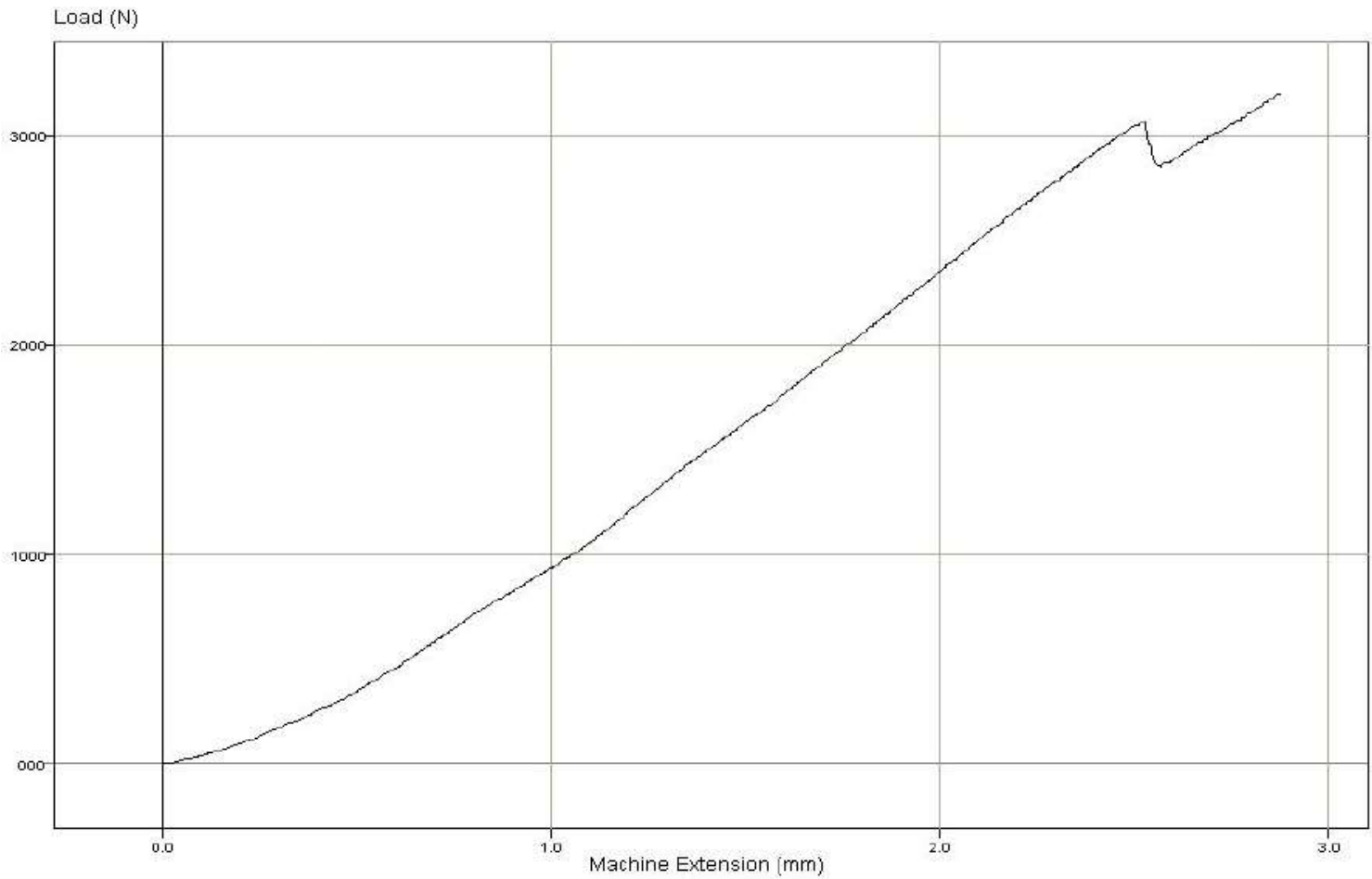

Figure 5. Maximum value for unprepared and unrestored teeth

Group G2 - prepared and unrestored teeth: the smallest load that determines the sample failure was $1043 \mathrm{~N}$ and the highest strength was $1588 \mathrm{~N}$, the mean value being $1325.25 \mathrm{~N} \pm 193.80 \mathrm{~N}$ (standard deviation). The diagram representing the maximum value is illustrated in Fig. 6.

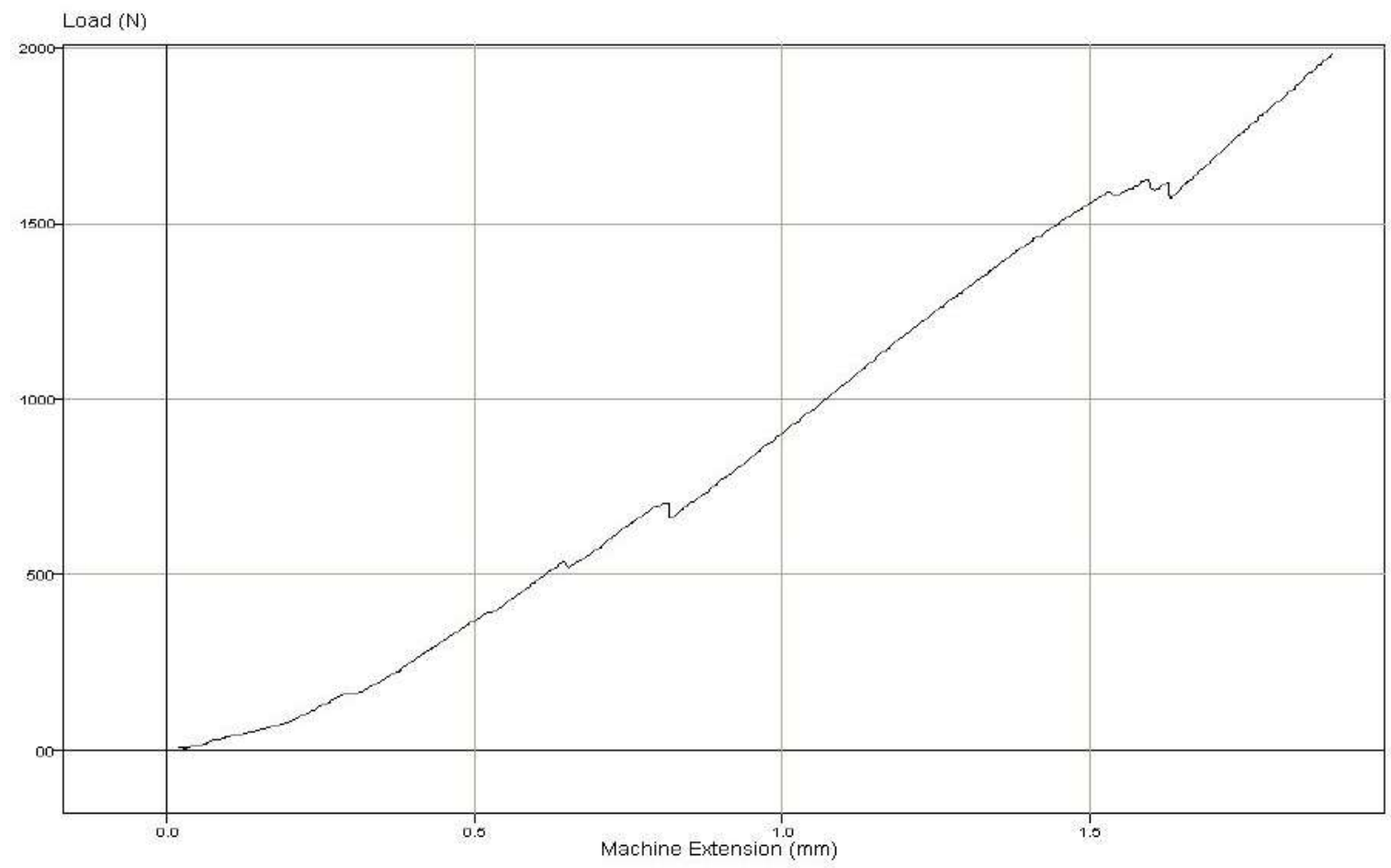

Figure 6. Maximum value for prepared and unrestored teeth 
Group G3 - prepared and restored teeth with ormocer: the smallest load that determines the sample failure was $1684 \mathrm{~N}$ and the highest strength was $2120 \mathrm{~N}$, the mean value being $1931.75 \mathrm{~N} \pm 169.20 \mathrm{~N}$ (standard deviation). The diagram representing the maximum value is illustrated in Fig. 7.

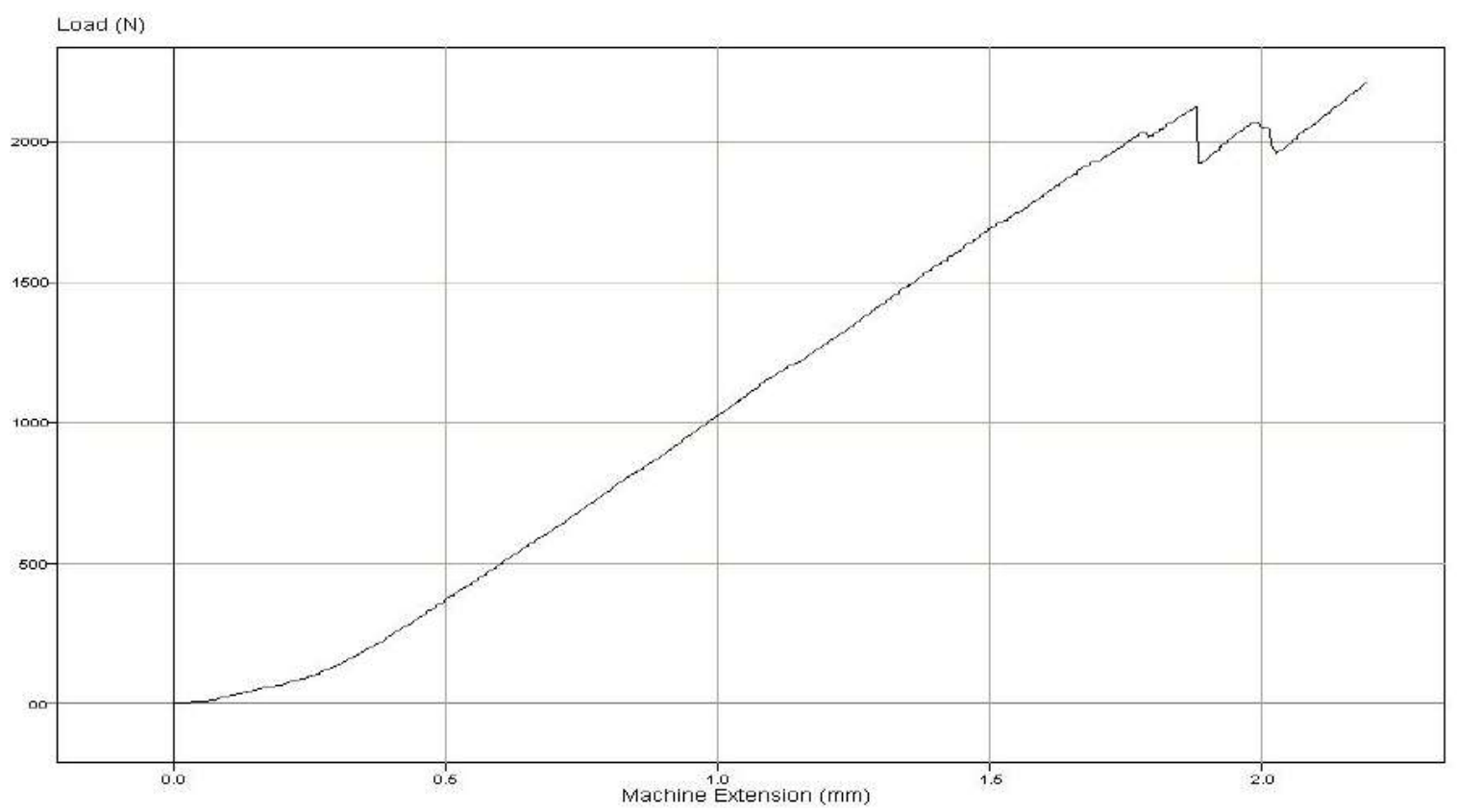

Figure 7. Maximum value for prepared and restored teeth with ormocer

Group G4 - prepared and restored teeth with nanofilled composite: the smallest load that determines the sample failure was $1445 \mathrm{~N}$ and the highest strength was $1955 \mathrm{~N}$, the mean value being $1703.12 \mathrm{~N} \pm 178.58 \mathrm{~N}$ (standard deviation). The diagram representing the maximum value is illustrated in Fig. 8.

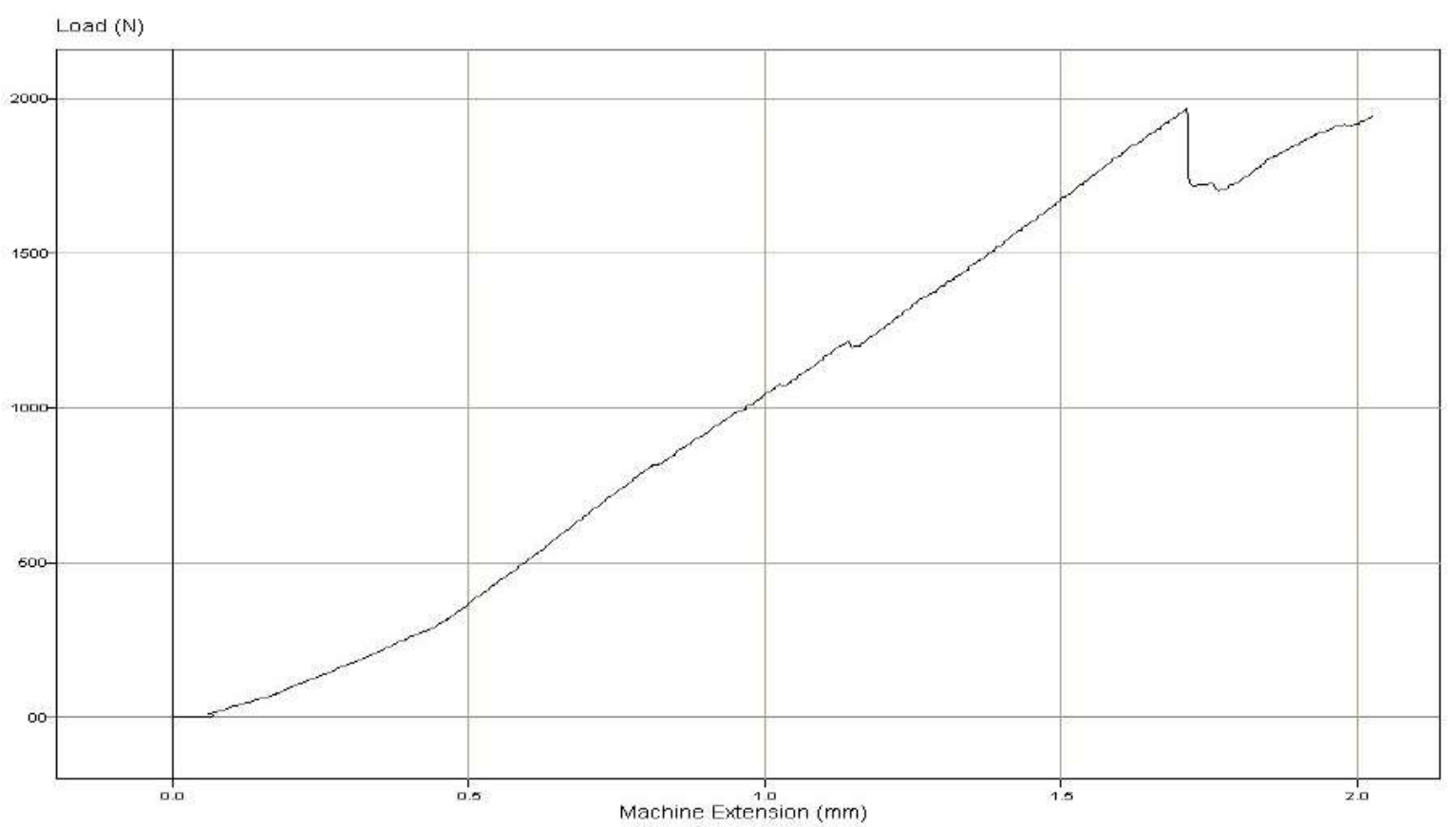

Figure 8. Maximum value for prepared and restored teeth with nanofilled composite 
Group G5 - prepared and restored teeth with mycrohibrid composite: the smallest load that determines the sample failure was $1500 \mathrm{~N}$ and the highest strength was $1798 \mathrm{~N}$, the mean value being $1645.87 \mathrm{~N} \pm 106.51 \mathrm{~N}$ (standard deviation). The diagram representing the maximum value is illustrated in Fig. 9.

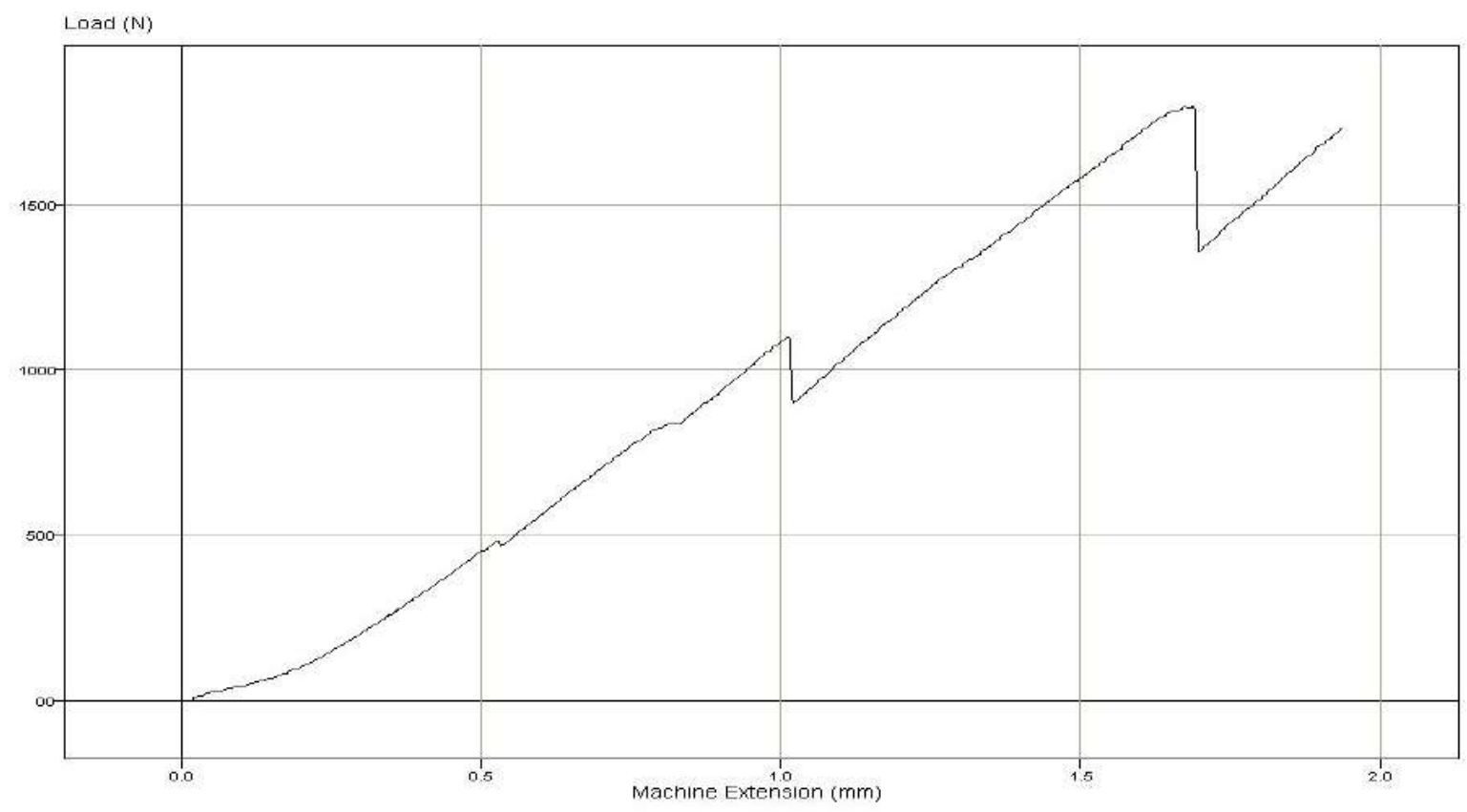

Figure 9. Maximum value for prepared and restored teeth with mycrohibrid composite

G1 presented the highest mean, whereas G2 presented the lowest. Regarding the fracture resistance of the restored teeth with aesthetic material, the highest resistance was revealed in the restored cavities with ormocer, the second place being located in case of restored cavities with nanofilled composite, the lowest stress resistance being recorded for the teeth restored with mycrohibride composite.

\section{Discussions}

The failures that may occur after the dental restorations of second-class cavities are represented by secondary caries, loss of fillings or dental fracture. Resistance to occlusal stresses depends on the type of composite used as a restorative material and its composition [16]. The Young Module of the materials is a parameter that can influence the fracture resistance of restored teeth [22]. In a study conducted by KAHLER et al. it was shown that the mechanical properties of restored teeth with composite materials are comparable to those of teeth without restorations [23]. DUPASQUIER et al. [24] and KOPLIN et al. [25] have shown that nanoceramic composite restored teeth have a stress behavior comparable with the teeth without restorations. A study conducted by LIU et al. [26] showed that in cases of MOD cavities with proximal boxes the composite resins showed a superior resistance to the fracture compared with ceramic materials. TAHA et al. compared the fracture resistance of some MOD cavities of premolars restorated by different filling materials (ormocer, nanofilled, nanoceramic, and microhybrid composite) [27] and showed that the best resistance to compression tests was recorded by the teeth restored with nanoceramic composite. Through the different elastic modulus of the four materials can be explained the different resistance of the restored teeth with ormocer, nanofilled, nanoceramic or microhybrid composite. Teeth restored with nanofilled composite have good resistant to fracture, being behind nanoceramic restored materials [27], and those restored with ormocers have shown a lower fracture resistance compared to unprepared teeth. The transmission of occlusal stresses and fracture resistance are different in the case of prepared-filling teeth and intact teeth [28]. Other studies in the literature showed that ormocers exhibit less shrinkage, and this, in addition to superior biological properties to conventional Bis-GMA materials, indicates it as an optimal material for dental restoration [29, 30]. A study conducted by Hamouda [1] shows that Admira an ormocer used for direct restoration - showed the highest fracture resistance, while restorations with packable composite resin showed a lower resistance to fracture. 
Ormocer-based restoration also provides fracture resistance of the restored tooth related as intact tooth. GUNWAL et al. [31] studied fracture resistance and mode of failure of premolars restored with nanohybrid composite, ormocer and ceramic inlays, and concluded that restored teeth with ormocer had the best fracture resistance comparable to natural teeth and indicated its use as a filling material for posterior teeth restoration. Also the results of our study are consistent with those found in the literature, showing a high fracture resistance of the teeth restored with ormocer, followed by those restored with nanofilled composite and then by those restored with mycrohibrid composite. The loadings that caused the samples failure for in vitro experiments are superior to those developed by the dento-maxillary system [32] in clinical situations, which is also highlighted in this study.

\section{Conclusions}

An important factor for ensuring a favorable prognosis of MOD cavities restorations is choosing the filling material. The type of chosen material can influence the compression resistance of the teeth. Among the materials analyzed in the study, mycrohibrid composite showed the lowest fracture resistance, followed by nanofilled composites, while the ormocer showed the highest resistance. Within the limitation of this in vitro study, it can be concluded that the teeth with second-class type MOD restored cavities with ormocers have a high compressive strength, which recommends the use of these materials to ensure the longevity of dental restorations.

\section{Conflict of Interests}

The authors declare that they have no conflict of interests.

\section{Author contribution}

All authors have equal contributions to this paper.

\section{References}

1. HAMOUDA IM. Fracture resistance of posterior teeth restored with modern restorative materials. J Biomed Res, 25, 418, 424 (2011).

2. KUGEL G. Direct and indirect adhesive materials: a review. Am J Dent., 13, 35D, 40D (2000)

3. SADIGHPOUR L, GERAMIPANAH F, RAEESI B. In Vitro mechanical tests for modern dental ceramics. J Dent (Tehran), 3(3), 143, 152 (2006).

4. FREITAS CR, MIRANDA MI, ANDRADE MF, FLORES VH, VAZ LG, GUIMARÃES C. Resistance to maxillary premolar fractures after restoration of class II preparations with resin composite or ceromer. Quintessence International, 33(8), 589, 594 (2002).

5. BOUILLAGUET S, WATALTA JC. Future Directions in bonding resins to the dentine-pulp complex. J Oral Rehabilit., 31, 385, 392 (2004).

6. GÖRÜCÜ J, ÖZGÜNALTAY G. Fracture resistance of teeth with class II bonded amalgam and new teeth-colored restorations. Oper Dent., 28(5), 501, 507 (2003).

7. JOYNT RB, WIECZKOWSKI G, JR, KLOCKOWSKI R, DAVIS EL. Effect of composite restorations on resistance to cuspal fracture in posterior teeth. J Prosthet Dent., 57, 931, 935 (1987).

8. SEGURA A, RIGGINS R. Fracture resistance of four different restorations for cuspal replacement. J Oral Rehabil., 26(12), 928, 931 (1999).

9. ST-GEORGES AJ, STURDEVANT JR, SWIFT EJ JR, THOMPSON JY. Fracture resistance of prepared teeth restored with bonded inlay restorations. J Prosthet Dent., 89(6), 551, 557 (2003).

10. BOYER DB, ROTH L. Fracture resistance of teeth with bonded amalgams. Am J Dent., 7, 91, 94 (1994).

11. SAGSEN B, ASLAN B. Effect of bonded restorations on the fracture resistance of root filled teeth. Int Endod J, 39, 900, 904 (2006).

12. DENEHY GE, TORNEY DL. Internal enamel reinforcement through micromechanical bonding. J Prosthet Dent., 36, 171, 175 (1976).

13. TAY FR, GWINNETT AJ, PANG KM, WEI SH. Variability in micro leakage observed in total each wet bonding technique under different handling conations. J Dent Res., 74, 1168, 1178 (1995).

14. BOWN RI, NEMOTO K, RAPSON OE. Adhesives of various materials to hard tissues: Force developing in composite materials during handling. JADA, 106, 975, 977 (1983).

15. HE Z, SHIMADA Y, TAGAMI J. The effects of cavity size and incremental technique on micro-tensile bond strength of resin composite in class I cavities. Dent Mater, 23, 533, 538 (2007).

16. BRAGA RR, FERRACANE JL. Alternatives in polymerization contraction stress management. Crit Rev Oral Biol Med, 15, 176, 184 (2004).

17. HEGDE V, SALI AV. Fracture resistance of posterior teeth restored with high-viscosity bulk-fill resin composites in comparison to the incremental placement technique. J Conserv Dent, 20, 360, 364 (2017).

18. ILIE N, FLEMING GJ. In vitro comparison of polymerisation kinetics and the micro-mechanical properties of low and high viscosity Giomers and RBC materials. J Dent, 43, 814, 822 (2015). 
19. ROSATTO CM, BICALHO AA, VERÍSSIMO C, BRAGANÇA GF, RODRIGUES MP, TANTBIROJN $D$ et al. Mechanical properties, shrinkage stress, cuspal strain and fracture resistance of molars restored with bulk-fill composites and incremental filling technique. J Dent, 43, 1519, 1528 (2015).

20. RAUBER GB, BERNARDON JK, VIEIRA LC, MAIA HP, HORN F, ROESLER CR et al. In vitro fatigue resistance of teeth restored with bulk fill versus conventional composite resin. Braz Dent J, 27, 452, 457 (2016).

21. OPDAM NJM, ROETERS JM. The effectiveness of bond- ed composite restorations in the treatment of pain- ful, cracked teeth: Six-month clinical evaluation. Oper Dent, 28, 327-333, (2003).

22. AUSIELLO P, APICELLA A, DAVIDSON CL, RENGO S. 3D-finite element analyses of cusp movements in a human upper premolar, restored with adhesive resin-based composites. J Biomech , 34, 1269, 1277 (2001).

23. KAHLER B, KOTOUSOV A, MELKOUMIAN N. On material choice and fracture susceptibility of restored teeth: An asymptotic stress analysis approach. Dent Mater, 22, 1109, 1114 (2006).

24. DUPASQUIER F, GRITSCH K, FARLAY D, ZYDOWICZ N, GROSGOGEAT B. Mechanical properties and polymer-ization shrinkage of dental nanohybrid composites. Eur Cells Mater, 13(suppl 1), 21 (2007).

25. KOPLIN C, JAEGER R, HAHN P. A material model for internal stress of dental composites caused by the curing process. Dent Mater, 25, 331, 338 (2009).
26. LIU X, FOK A, LI H. Influence of restorative material and proximal cavity design on the fracture resistance of MOD inlay restoration. Dent Mater, 30, 327, 333 (2014).

27. TAHA DG, ABDEL-SAMAD AA, MAHMOUD SH. Fracture resistance of maxillary premolars with class II MOD cavities restored with Ormocer, Nanofilled, and Nanoceramic composite restorative systems. Quintessence Int., 42(7), 579, 587 (2011).

28. BHARDWAJ TP, SOLMON P, PARAMESWARAN A. Tooth RESTORED with composite resin - A comparative analysis. Trends Biomater Artif Organs, 15, 57, 60 (2002).

29. BOUILLAGUET S, SHAW L, GONZALEZ L, WATAHA JC, KREJCI I. Long term cytotoxicity of resin- based dental restorative materials. J Oral Rehabil., 29, 7, 13 (2002).

30. FRANZ A, FRANZ K, MARGIT A, XIAOHUI RF, GABRIELE G, WOLF DR et al. Cytotoxic effect of pack able and non packable dental composites. Dent Mater., 19, 382-92, (2003).

31. GUNWAL MK, SHENOI PR, PARANJAPE T, DHOTE S, TONGYA R, KUMAR M, RASTOGI S. Evaluation of fracture resistance and mode of failure of premolars restored with nanohybrid composite, ormocer and ceramic inlays. J Oral Biol Craniofac Res., 8(2), 134, 139 (2018).

32. GIBBS CH, MAHAN PE, MAUDERLI A, LUNDEEN HC, WALSH EK. Limits of human bite strength. J Prosthet Dent., 56, 226, 229 (1986). 